\title{
DOES TRAUMA FAVOUR THE OCCURRENCE OF THE ECHINOCOCCUS IN THE ORBIT?
}

\author{
BY \\ V. P. Patel \\ KARACH I
}

RECENTLY, in March, 1932, Dudinow reported a case of an "Echinococcus of the orbit and trauma" in Klin. Monatsbl. $f$. Augenheilk., Vol. LXXXVIII, p. 373. His patient was a boy, aged 12 years, who developed a cyst of the left orbit following an injury by a donkey's kick.

I came across an exactly similar case in May, 1932. A Mohommedan boy, aged 12 years, came to the Mohatta Eye Hospital, Karachi, India, with a swelling of the size of a small orange, in the

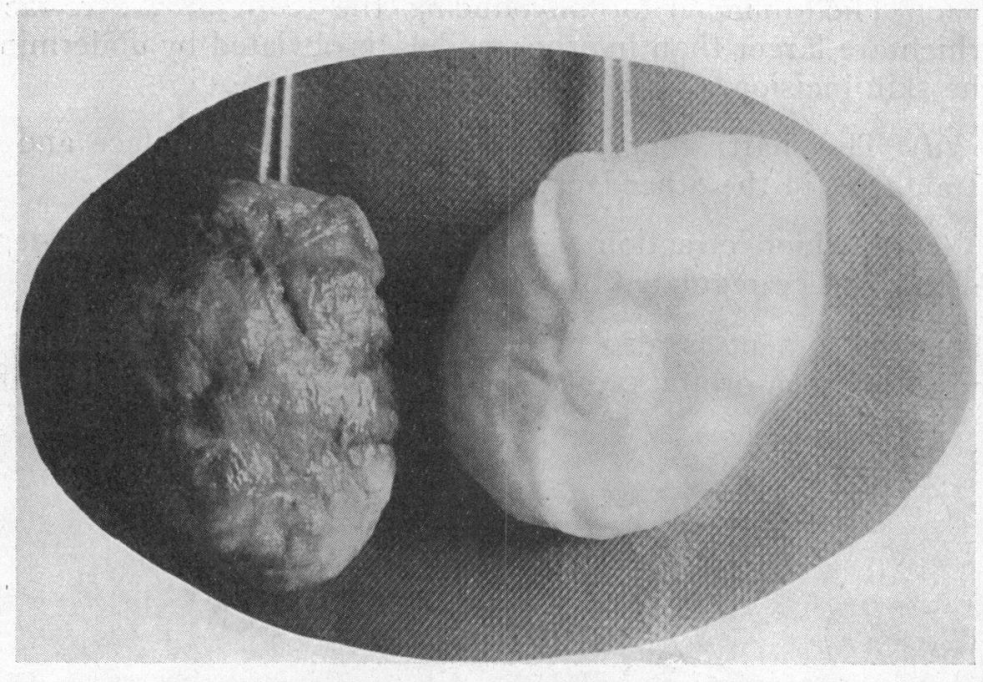

No. I.

No. II.

Tissue reaction cyst.

Hydatid cyst.

region of the right lower lid and cheek. The eyeball was pushed upwards and inwards and the lower corneal edge could be seen with difficulty. The boy's mother gave the history that the boy was kicked by a donkey six months previously, and since that date the swelling had gradually increased day by day. A clinical diagnosis of an intra-orbital cyst was made and on removal it was found to be an unilocular hydatid cyst.

As in Dudinow's case, trauma seems to have favoured the occurrence of the echinococcus in the orbit. 